\title{
USE OF DENOSUMAB IN GIANT-CELL TUMOR AT A PUBLIC HOSPITAL IN SOUTHERN BRAZIL: REPORT OF 13 CASES.
}

\author{
USO DE DENOSUMAB EM TUMOR DE CÉLULAS GIGANTES EM HOSPITAL PÚBLICO NO SUL DO BRASIL: \\ RELATO DE 13 CASOS.
}

Tamise da Silva Baptista1,*, Lucilda Cerqueira Lima1', Aline Rocha Lino', Gerson Gandhi Ganev', Paulo Kechele', Rita Ferrúa Farias de Oliveira'.

\begin{abstract}
Giant-cell tumor is a relatively rare neoplasia, benign but locally aggressive, that causes significant bone destruction with predilection for epiphyseal and metaphyseal regions of long bones and the spine. Definitive treatment is surgical, with complete tumoral resection followed by autograft, homograft, arthrodesis, unconventional endoprostheses or methylmethacrylate. In most cases, surgery is accompanied by high morbidity and variable recurrence rates, depending on the site, size and type of surgical intervention.Denosumab, a RANKL inhibitor, acts by decreasing tumoral osteoclastic activity and is approved by the Food and Drug Administration for treatment of GCT when surgery is not possible or when it is associated with high morbidity. This report of cases is based on the review of medical records from the Ambulatory Service for Adolescents and Young Adults (AYA), aiming to show the experience of the Service with the use of denosumab for neoadjuvant purposes.
\end{abstract}

Keywords: Denosumab; RANK Ligand; Giant Cell Tumors.

\section{RESUMO}

O tumor de células gigantes é uma neoplasia relativamente rara, benigna, mas localmente agressiva, que causa destruição óssea significativa, com predileção por regiões epifisárias e metafisárias de ossos longos e da coluna vertebral. O tratamento definitivo é cirúrgico, com ressecção tumoral completa seguida de autoenxerto, homoenxerto, artrodese, endoprótese não convencional ou metilmetacrilato. Na maioria dos casos, a cirurgia é acompanhada por alta morbidade e taxas variáveis de recorrência, dependendo do local, tamanho e tipo de intervenção cirúrgica. O denosumabe, um inibidor da RANKL, atua diminuindo a atividade osteoclástica tumoral e é aprovado pela Food and Drug Administration para o tratamento do TGC quando a cirurgia não é possível ou quando está associada a alta morbidade. Este relato de casos baseia-se na revisão de prontuários do Serviço Ambulatorial de Adolescentes e Jovens Adultos (AJA), com o objetivo de mostrar a experiência do Serviço com o uso de denosumabe para fins neoadjuvantes.

Descritores: Denosumab; Ligando RANK; Tumores de Células Gigantes.

\footnotetext{
1. CENTRO DE PESQUISAS ONCOLÓGICAS - CEPON, Ambulatório de Atendimento aos Adolescentes e Jovens Adultos - AJAS - FLORIANÓPOLIS -
} Santa Catarina - Brazil

Financial support: none to declare.

Conflicts of interest: The authors declare no conflict of interest relevant to this manuscript.

Correspondence author: Tamise da Silva Baptista. CEPON - CENTRO DE PESQUISAS ONCOLÓGICAS.

Rod. Admar Gonzaga, 655. Itacorubi, Florianópolis - SC, Brazil. Zip code: 88034-000. Phone: +55 4899626110.

E-mail: tamise_baptista@hotmail.com. 


\section{INTRODUCTION}

Giant-cell tumor (GCT) is a relatively rare neoplasia, benign but locally aggressive, that causes significant bone destruction, and it has predilection for epiphyseal and metaphyseal regions of long bones and the spine. $^{1,2,3}$

It represents 4 to $10 \%$ of primary tumors of bone, reaching 20\% in China. It also represents $20 \%$ of benign tumors of bone and it was described as a separate entity in the beginning of the last century, being called sarcoma of giant cells. ${ }^{4}$

The GCT occurs mainly in young adults aged between 20 and 40 years old. Pediatric cases are much less frequent and represent only $1.7 \%$ of all cases of giant-cell tumors. ${ }^{5}$

Despite the benign nature of the disease, giant-cell tumors can have a highly variable and unpredictable behavior, and frequently recur after surgical resection. In addition, approximately 3\% metastasize to lungs. ${ }^{5}$ Even though some patients have high rate of survival after their pulmonary metastases, distant metastases do not usually respond well to chemotherapy. ${ }^{6}$ Recurrent tumors can suffer transformation into malignant osteoclastoma, fibrosarcoma or osteosarcoma. The radiotherapy treatment can lead to high-grade sarcomas (less than $1 \%$ of treated patients) or to the development of a second neoplasia (up to $15 \%$ of treated patients). ${ }^{7}$

Usually, patients suffer pain, and often have deformities at the primary site of neoplasia, without constitutional symptoms. $^{5}$ In rarer cases, the diagnosis is based on a palpable mass or pathological fracture, or on fortuitous discoveries from imaging exams in the absence of the symptoms. ${ }^{4}$

Definitive treatment is surgical, with complete tumoral resection, followed by autograft, homograft, arthrodesis, unconventional endoprostheses or methylmethacrylate. In most cases, surgery is accompanied by high morbidity and variable recurrence rates ranging from 10 to $75 \%$ of the cases, depending on the site, size and type of surgical intervention. 8

We know that, histologically, GCT is constituted by a stroma with ovoid or spindle- shaped cells, with the presence of giant cells similar to osteoclasts. The giant cells of this tumor express RANK and its stroma expresses its ligand (RANKL). ${ }^{9}$

The RANK receptor is a key mediator of osteoclastogenesis and it is stimulated by the cytokine RANKL, which is secreted by stromal cells. ${ }^{10}$

In normal physiological conditions, there is a balance between RANK, RANKL and osteoprotegerin, components of the RANK route, where the RANK L produced by the osteoblasts binds to RANK on the surface of the osteoclasts, promoting bone resorption, formation, activation and survival of the osteoclasts. ${ }^{11}$

We observed that the high expression of RANKL by cells of tumoral stroma stimulates giant-cells formation similar to osteoclasts, which promote aggressive osteolytic action.

Associated with an environment with intense production of cytokines and factors of tumoral growth, it intensifies the expression of RANKL and decreases the expression of osteoprotegerin in the osteoblasts, leading to an increment of the function and to the distinction of the osteoclasts and, hence, to higher osteoclastic activity. ${ }^{11}$

Denosumab, a RANKL inhibitor, approved by the Food and Drug Administration (FDA) for treatment of GCT when surgery is not possible or when it would have high associated morbidity, is a powerful mediator of the osteoclastic activity, inhibiting the performance of the ligand for RANK and decreasing the tumoral osteoclastic activity as a result. ${ }^{6}$

The Ambulatory Service for Adolescents and Young Adults (AYA) is a service for adolescents and young adults with cancer within the health public system of the State of Santa Catarina and is a referral center for the entire state for treatment of sarcomas and bone tumors. Therefore, the mentioned service presents a large group of patients with this pathology and it has desonumab available for the selected cases of patients with giant-cells tumors.

This study aims to introduce the service experience using denosumab in patients with GCT at a cancer hospital in Florianópolis, State of Santa Catarina, from May 2011 to February 2018.

\section{DESCRIPTION OF CASES}

This report of cases is based on review of medical records conducted by AYA. All cases of GCT from the institution were included in this analysis, which aims to describe the Service experience using denosumab in 13 studied patients from May 2011 to February 2018 at the Oncological Research Center (CEPON).

After medical record review, we selected locally advanced GCTs, confirmed by histopathological diagnosis, for use of desonumab for neoadjuvant purposes. All cases received subcutaneous injection of desonumab $120 \mathrm{mg}$ once a week during three consecutive weeks in the initial phase (followed by once a month), with pre-surgical intent. The selected cases for desonumab use presented unresectable disease, likelihood of high morbidity after surgery (for example, amputation, loss of movement) or pulmonary metastasis.

Patients were classified according to their age when diagnosed, sex, site, desonumab duration of use, time to surgery, pathological response to surgery, time to 
recurrence and follow-up duration. All were followed up by radiological images, including $\mathrm{x}$-rays, computed tomography scanning and/or magnetic resonance imaging. In general, patients were subjected to an imaging exam of the primary site every four to six cycles in order to have their responses assessed. They received desonumab until there was lesion stabilization or enough decrease for safety resection.

We considered the follow-up duration as the time relapsed since the beginning of the use of desonumab until the date of the last imaging or anatomopathological exam (AP) registered on patient medical records. The period of recurrence was defined as the time relapsed between the end of denosumab use and the date of recurrence evidenced by an imaging exam.

\section{Authors had no conflict of interest in this report of cases.}

A total of 13 cases were selected for this review: $53.8 \%$ (7/13) male patients and $46.2 \%$ female patients. When classified by site, the most affected regions in descending order were: tibia (5/13), distal radius
(3/13), femur (2/13), fibula (1/13), maxilla/mandible (1/13) and scapula (1/13). Among the 13 analyzed cases, there were two patients with diagnosed pulmonary metastases, whose initial treatment was chemotherapy based on cisplatin and doxorubicin. These patients were diagnosed some years before the availability of desonumab at the institution. Among the other patients, desonumab was elected for the initial treatment in eight cases and in three of them desonumab was started in our institution after prior surgical intervention at other centers (Table 1).

Regarding surgery after use of desonumab, among all patients under treatment, one was still receiving it, one missed follow-up and six underwent surgery. Among those who underwent surgery, two of them had no AP exam available. Regarding those cases that had not undergone surgery, (four patients in total) the reasons were as follows: choice, metastases (two) and pregnancy. Thus, when AP exams were assessed after the use of desonumab in non-metastatic patients, of the six patients who had undergone surgery, four of them showed changes related only to the use of the drug and without evidence of the disease (Table 1).

Table 1. Characteristics of patients.

\begin{tabular}{|c|c|c|c|c|c|c|c|}
\hline PATIENT & AGE & SITE & $\begin{array}{l}\text { DESONUMAB } \\
\text { INITIAL } \\
\text { TREATMENT } \\
\end{array}$ & $\begin{array}{c}\text { TIME BETWEEN } \\
\text { DESONUMAB } \\
\text { SURGERY (DAYS) }\end{array}$ & $\begin{array}{l}\text { AP: CHANGES } \\
\text { RELATED TO } \\
\text { DESONUMAB } \\
\end{array}$ & $\begin{array}{c}\text { TIME TO } \\
\text { RECURRENCE } \\
\text { (MONTHS) } \\
\end{array}$ & $\begin{array}{l}\text { FOLLOW-UP } \\
\text { (MONTHS) }\end{array}$ \\
\hline 1 & 31 & $\begin{array}{l}\text { Proximal } \\
\text { femur (L) }\end{array}$ & No & $\mathrm{FL}$ & $\mathrm{FL}$ & 13 & $\mathrm{FL}$ \\
\hline 2 & 32 & $\begin{array}{l}\text { Proximal } \\
\text { epiphysis } \\
\text { fibula (L) }\end{array}$ & Yes & 22 & YES & $\begin{array}{c}\text { W/O ED } \\
\text { CT 01/2017 }\end{array}$ & 40 \\
\hline 3 & 28 & $\begin{array}{c}\text { Distal } \\
\text { extremity of } \\
\text { scapula (R) }\end{array}$ & Yes & $* *$ & - & $\begin{array}{c}\text { W/O ED } \\
\text { MRI 04/2017 }\end{array}$ & 47 \\
\hline 4 & 39 & $\begin{array}{l}\text { Distal radius } \\
\text { (L) }\end{array}$ & No & $*$ & - & 13 & 65 \\
\hline 5 & 33 & Tibia (L) & No & $*$ & - & $\begin{array}{l}\text { W/O ED } \\
\text { CT 05/2017 }\end{array}$ & 61 \\
\hline 6 & 22 & $\begin{array}{l}\text { Maxilla and } \\
\text { Mandible (R) }\end{array}$ & Yes & 1 & YES & $\begin{array}{c}\text { W/O ED } \\
\text { MRI 04/2017 }\end{array}$ & 56 \\
\hline 7 & 24 & Tibia (L) & No & $\star \star \star$ & - & $\begin{array}{c}\text { W/O ED } \\
\text { MRI 09/2017 }\end{array}$ & 33 \\
\hline 8 & 44 & $\begin{array}{l}\text { Proximal tibia } \\
\text { (R) }\end{array}$ & Yes & RDT & - & $\begin{array}{c}\text { SD } \\
\text { MRI } 11 / 2017\end{array}$ & 36 \\
\hline 9 & 39 & $\begin{array}{l}\text { Distal radius } \\
(\mathrm{R})\end{array}$ & Yes & 29 & YES & $\begin{array}{c}\text { W/O ED } \\
\text { MRI 08/2017 }\end{array}$ & 18 \\
\hline 10 & 19 & $\begin{array}{l}\text { Proximal tibia } \\
\text { (L) }\end{array}$ & Yes & 25 & W/O AP & 21 & 27 \\
\hline 11 & 21 & $\begin{array}{l}\text { Distal radius } \\
(\mathrm{R})\end{array}$ & Yes & 81 & YES & $\begin{array}{l}\text { W/O ED } \\
\text { Surgery: } \\
\text { 04/05/18 }\end{array}$ & 18 \\
\hline 12 & 18 & $\begin{array}{l}\text { Distal femur } \\
\text { (R) }\end{array}$ & Yes & 63 & W/O AP & $\begin{array}{c}\text { W/O ED } \\
\text { MR 02/2018 }\end{array}$ & 18 \\
\hline 13 & 28 & $\begin{array}{c}\text { Proximal tibia } \\
(\mathrm{L})\end{array}$ & No & $\begin{array}{l}\text { Currently } \\
\text { receiving }\end{array}$ & - & - & -- \\
\hline
\end{tabular}

AP: anatomopathological; R: right; L: left; W/O ED: without evidence of disease; SD: stable disease; FL: follow-up loss; *: metastatic; **:no surgery (patient's choice); ***: no surgery (pregnancy); CT: computed tomography; MRI: magnetic resonance imaging 
By analyzing the metastatic pulmonary patients, \#4 showed excellent radiological response, received desonumab for 13 months, with complete pulmonary response and partial response in primary lesion. He missed his follow-up at CEPON, and returned to the hospital with local recurrence 13 months after the end of desonumab infusion, resuming his treatment. This patient received his second desonumab exposure during 12 months, with control of local disease for another seven months. He presented progression of the local disease and was treated with radiotherapy (RDT) from November to December 2016, totalizing 60Gy. In October 2017, 11 months after RDT, he evolved with pulmonary progression and was currently receiving desonumab again, since December 8, 2017. Patient \#5, also metastatic when diagnosed, had no evidence of recurrence until May 2017, taking into account his tomography of the lower left limb and thorax exams shown during his follow-up on that date (Table 1).

Among the six patients who had received desonumab and had subsequently undergone surgery, four of them remained without evidence of the disease (Table 1).

When we analyzed patients who had not undergone surgery, one of them because she was pregnant and another due to personal choice, we noticed that they had no evidence of recurrence until the end of this study.

All studied patients very well tolerated the use of desonumab and no degree of toxicity was reported. All patients took vitamin D and went through calcium replacement.

\section{DISCUSSION}

The GCT is considered a benign tumor but has the potential of being locally aggressive and presenting significant levels of recurrence, even after complete resection. Notwithstanding its benign nature, there are reports of pulmonary metastatic disease confirmed in two of our patients (15\%). Our retrospective also showed agreement with the age group of higher incidence in previous reports (20 to 40 years old): average of 29 years old, with ages ranging from 18 to 44 years of age. Regarding to sites, literature shows preference for distal femur and proximal tibia, which meets the results of this study, from which a predominance of tibia was observed, corresponding to $38 \%$ of patients.

Denosumab was approved by FDA in June 2013 for treatment of GCT whereof disease is unresectable or when surgery will bring high morbidity. We follow these same indications regarding the use of denosumab in our service. ${ }^{13}$

Some cases presented in this report received desonumab after surgical treatment because they were treated in other institutions where desonumab was not available yet. We noticed five cases in which desonumab was not the first treatment. Two of them had metastatic disease and had been submitted to previous chemotherapy. The three other cases came from other services due to tumor recurrence after previous surgery.

The average time elapsed between the end of desonumab treatment and surgery was 36 days, in agreement with the mean time reported in other similar studies. According to Mc Carthy et al, considering five patients assessed in their study, this time ranged from 18 to 39 days. $^{14}$

Regarding the recurrence rate, after receiving desonumab and complete radiological response, patient \#1 was monitored with locoregional recurrence of the disease during 13 months, when he missed his follow-up. Still within the group of recurrent patients, we had metastatic patient \#4 with recurrence after 13 months and patient \#10 (who underwent surgery) with recurrence after 21 months.

By considering the other patients, among those who underwent surgery, we noticed that the longest followup without evidence of the disease was four years and eight months (patient \#6, who underwent surgery).

Regarding those patients who did not undergo surgery, patient \#8 was submitted to RDT (due to limiting comorbidities), drawing attention due to a stable disease after 36 months of follow-up. Patients \#3 (who refused surgery) and \#7 (pregnant) also stand out. The former due to 47 months without evidence of the disease, and the latter, due to 33 months of follow-up without evidence of the disease.

With the exception of a metastatic patient (1), a missed follow-up (1), a recurrence of the disease (1) and a current use of desonumab (1) -, of the 13 assessed patients, eight patients had no evidence of recurrence until completion of this study. There was one patient with stable disease after radiotherapy.

The recurrence rates, according to studies, can vary from 16 to 30\%, with higher recurrences rates for distal radius, followed by distal tibia. ${ }^{15}$ In our study, there was only one recurrence of localized disease of the proximal tibia, treated with re-exposure to desonumab. This patient was still receiving it at the completion of this review.

The proposed study clearly shows some limits, mainly due to the difficulty of standardization of common procedures in Brazilian public hospitals, which face difficulties of executing more complex imaging exams, such as computed tomography and magnetic resonance imaging. Thus, not every patient presents controlling imaging exams after the same number of cycles of desonumab. In spite of this, the significant number of cases of GCT in our institution is remark- 
able, where treatment procedures are in accordance with international guidelines. In addition, tolerance to the drug similar to the medical literature without significant toxicities was observed.

We concluded that desonumab treatment of GCT is a relevant one, once we provided our patients with a less aggressive treatment and with encouraging results, from complete responses after surgery or without any evidence of the disease, even in cases of patients who did not undergo surgery.

Desonumab is already a recognized drug in this context; however, due to the low incidence of this disease, we have little data regarding its treatment as a result.

This study further reiterates the role of such an important drug for treatment of giant- cells tumor.

\section{AUTHOR'S CONTRIBUTION}

Tamise da Silva Baptista: Collection and assembly of data, Conception and design, Data analysis and interpretation, Final approval of manuscript, Manuscript writing, Provision of study materials or patient.

Rita Ferrua: Collection and assembly of data, Conception and design, Data analysis and interpretation, Final approval of manuscript, Manuscript writing, Provision of study materials or patient.
Lucilda Cerqueira Lima: Collection and assembly of data, Conception and design, Data analysis and interpretation, Final approval of manuscript, Manuscript writing, Provision of study materials or patient.

Aline Rocha Lino: Collection and assembly of data, Data analysis and interpretation, Manuscript writing.

Gerson Gandhi Ganev: Conception and design, Final approval of manuscript, Provision of study materials or patient.

Paulo Kechele: Conception and design, Final approval of manuscript, Provision of study materials or patient.

\section{REFERENCES}

1. Agarwal A, Larsen BT, Buadu LD, Dunn J, Crawfor R, Daniel J, et al. Denosumab Chemotherapy for recurrent giant-cell tumor of bone: a case report of neoadjuvant use enabling complete surgical resection. Case Reports in Oncological Medicine 2013; 2013:1-4.

2. Schwartz HS. Giant Cell Tumor of bone. Comprehensive Therapy 1993;19(2):64-68.

3. Mendenhall WM, Zlotecki RA, Scarborough MT, Gibbs CP, Mendenhall NP. Giant- cell tumor of bone. American Journal Clinical Oncology 2006; 29(6):96-99.

4. Dufresne A, Derbel O, Cassier P, Vaz G, Decouvelaere A, Blay J. Giant-cell tumor of boné, anti-RANKL therapy. Bonekey Reports 2012; 1(149):1-8.

5. Karras NA, Polgreen LE, Ogilvie C, Manivel JA, Skubitz KM, Lipsitz E. Denosumab treatment of metastatic giant-cell tumor of bone in a 10-yearold girl. Journal of Clinical Oncology 2013; 31(13):200-202.

6. XU SF, Adams B, Yu XC, Xu M. Denosumab and giant cell tumor of bone - a review and future management considerations. Current Oncology 2013,20(5):442-447.

7. Chakarun CJ, Foster DM, Gottsegen CJ, Patel DB, White EA, Matcuk GR. Giant cell tumor of bone: review, mimics, and new developments in treatment. Radiographics 2013; 33(1):197-211.
8. DeVita VT, Lawrence TS, Rosenberg SA. Cancer Principles and Practice of Oncology. 10th ed. Philadelphia: Wolters Kluwer Health, 2014.

9. Thomas D, Henshaw R, Chawla S, Staddon A, Blay J, Roudier $\mathrm{M}$, et al: Denosumab in patients with giant-cell tumour of bone: an open-label, phase 2 study. Lancet Oncology 2010;11(3): 275-280.

1. 10. Sobti A, Agrawal P, Agarwala S, Agarwal M. Giant Cell Tumor of Bone - An Overview. Arch Bone Jt Surg 2016; 4(1): 2-9.

11. Wu P, Tang WJ, Li K: RANK pathway in giant cell tumor of bone: pathogenis and therapeutic aspects. Tumor Biology 2015;36(2):495-501.

12. NCCN. National comprehensive cancer network. Clinical practice guidelines in oncology [Internet]. Bone cancer, 2018. Available from: http:// www.ncen.org.

13. FDA. Food and drug administration registration, 2018. Available from: https://www.accessdata.fda. gov/drugsatfda_docs/label/2013/125320s094lbl. pdf.

14. McCarthy $\mathrm{CL}$, Gibbons CLMH, Bradley KM, Hassan $A B$, Giele $H$, Athanasou NA. Giant cell tumour of the distal radius/ulna: response to pre-operative treatment with short-term denosumab. Clinical Sarcoma Research 2017;7:1-11.

15. Balke M, Schremper L, Gebert C, Ahrens H, Streitbuerger A, Koehler G, et al. Giant ell tumor of bone: treatment and outcomes of 214 cases. Journal of Cancer Clinical Oncology 2008;134(9):969-978. 